African Crop Science Journal by African Crop Science Society is licensed under a Creative Commons Attribution 3.0 Uganda License. Based on a work at www.ajol.info/ and www.bioline.org.br/cs DOI: https://dx.doi.org/10.4314/acsj.v29i1.10

\title{
MAPPING OF SOIL NUTRIENT DEFICIENCY IN OIL PALM PLANTATIONS OF SOUTHERN BENIN
}

\section{N.S. KINDOHOUNDÉ ${ }^{1,2}$, L. NODICHAO ${ }^{1}$, N.S.H. AHOLOUKPÈ ${ }^{1}$ and A. SAÏDOU ${ }^{2}$}

${ }^{1}$ Institut National des Recherches Agricoles du Bénin (INRAB)/Centre de Recherches Agricoles sur les Plantes Pérennes (CRA-PP) BP. 01 Pobè, Bénin

${ }^{2}$ Unité de Recherche sur la Gestion Intégrée des Sols et des Cultures (ISCM), Laboratoire des Sciences du Sol, Ecole des Sciences et Techniques de Production Végétale, Faculté des Sciences Agronomiques (FSA), Université d'Abomey-Calavi (UAC) Bénin, 04 BP 1510 Cadjèhoun, Cotonou, Bénin

Corresponding author: kindohoundenarcisse@ymail.com

(Received 9 June 2020; accepted 17 February 2021)

\begin{abstract}
Soil degradation poses a threat to sub-Saharan sustainability of agriculture namely because of chemical and physical degradation. The objective of this study was to characterise soil properties in oil palm plantation in the districts of Ouémé and Plateau and develop spatial maps for soil nutrients useful in agricultural land use as a basis for designing soil fertility management strategies. A survey carried out in oil palm (Elaeis guineensis Jacq.) plantations in the southern Benin, revealed mineral deficiency symptoms consequent to poor mineral nutrition of the plant. A total of 428 soil composite samples were collected under farmers' adult oil palm trees, randomly selected. These oil palm plantations were located on four soil types: Acrisol, Plintics and luvisols, Hydromorphic soil and Vertisols. In total, 370 samples were collected on plantations under Acrisols, 22 samples under Plintics and luvisols, 26 samples under Hydromorphic soil and 10 samples under Vertisols. Geostatistic methods were used to determine the spatial variability; and semi-variogram methods were established using ordinary kriging. A strong spatial dependency for nitrogen, phosphorus, potassium and magnesium was observed; while spatial dependency of calcium was moderated. The map of nutrient deficiency revealed two large areas. The first, included the districts of Bonou, Adjohoun, Sakété, Adja-Ouèrè, and Pobè, where oil palm plants showed an acute nitrogen, phosphorus and potassium deficiency; and the second area of Dangbo, Missérété, Ifangni, Avrankou, Adjarra which presented nitrogen, potassium and slight phosphorus deficiency in the oil palm plantations. Most of the soils under the oil palm plantations showed nitrogen, phosphorus and potassium deficiency.
\end{abstract}

Key Words: Deficiency mapping, nutrient deficiency, semivariogram 
Afin d'apporter une solution à la manifestation des symptômes de déficience minérale dans les plantations paysannes de palmier à huile, la présente étude vise à déterminer la variabilité spatiale des déficiences en nutriments au niveau de trois types de sol au sud Bénin pour une cartographie des manifestations. A cet effet, 428 échantillons composites de sol ont été collectés au niveau des plantations paysannes de palmier à huile sur sols Ferrallitiques, sols Ferrugineux tropicaux, sols Hydromophes et Vertisols. Au total 370 échantillons ont été prélevés au niveau des sols Ferrallitiques, 22 au niveau des sols Ferrugineux tropicaux, 26 au niveau des sols Hydromorphes et 10 au niveau des Vertisols. La géostatistique a permis de déterminer la variabilité spatiale des carences minérales des sols et les semivariogrammes ont été établis à l'aide du krigeage ordinaire. Un grand nombre d'arbres ont présenté des carences en azote, phosphore, potassium et magnésium, en revanche, la dispersion spatiale des arbres présentant une carence en calcium était modérée. La cartographie des déficiences minérales des sols a révélé deux grandes zones similaires : la première présentant des signes de carence en azote, phosphore et potassium regroupe les communes de Bonou, Adjohoun, Sakété, Adja-Ouèrè, et Pobè, la seconde constituée des communes de Dangbo, Missérété, Ifangni, Avrankou, Adjarra avec des palmeraies présentant des signes de carence sévère en azote et potassium et des signes de carence moins prononcés en phosphore.

Mots Clés : Cartographie des carences, carences nutritionnelles, semivariogramme

\section{INTRODUCTION}

Soil degradation poses a threat to sub-Saharan sustainability of agriculture mainly because of chemical and physical degradation. The loss of soil organic matter ( $\mathrm{SOM}$ ), nutrient depletion, soil erosion and changes in soil structure are by far the most outstanding phenomena (Seutloali and Beckedahl, 2015). In Benin, especially in the Ouémé and Plateau districts, selective establishment of oil palm plantations in the past led to the conversion of forests into oil palm plantations. This contributed to increase of oil palm plantation area from 867 ha in 1997 to 16,000 ha in 2012 (Adjadi et al., 2012). This forest conversion into palm oil plantations, drained soil fertility depending on plantation age (Dewi, 2007). This change in soil properties will be more crucial if farmers do not apply fertilisers to supply nutrients to the plants, as it is the case in the Ouémé and Plateau districts where about 50.09 and $58.5 \%$, respectively, of the oil palm plantations are not fertilised (Kindohoundé et al., 2018). In fact, in the farmers' oil palm plantations in the south Benin, several leaves were discolored and deformed, displaying chlorosis, orange spots, wavy and embossed leaves, stunted/malformed leaves and white strips, mostly typical of nitrogen and potassium deficiencies as well as probable boron and magnesium deficiencies. On average, $45.92 \%$ nutrient deficiency symptoms manifested with a weak appearance symptom in the fertilised oil palm plantation. This calls for appropriate soil management actions to improve the yield of farmers' oil palm plantation.

Furthermore, micro variability of soil under oil palm plantation in the districts of Ouémé and Plateau in Benin is weakly studied, and fertilisers are applied without recommendation. In general, the spatiotemporal variation of physical, chemical and biological processes, as well as the anthropogenic land use patterns and the combination of their action, may result in spatial variability of soil properties (Goovaerets, 1998).

The objective of this study was to characterise soil properties in oil palm plantation in the districts of Ouémé and Plateau 
with a view to developing spatial maps for soil nutrients useful in agricultural land use and designing of soil fertility management strategies.

\section{MATERIALS AND METHODS}

Study area. The study was carried in the districts of Ouémé (especially in the districts of Bonou, Adjohoun, Dangbo, Missérété, Avrankou and Adjarra) and Plateau (Ifangni, Sakété, Adja-Ouèrè and Pobè) located in the south-East of Benin (Fig. 1). These two districts are under a sub-equatorial climate, with an alternation of two rainy seasons from March to July and from September to November. Acrisols (dominant), Vertisols (at Pobè and Adja-Ouèrè), hydromorphic soils (in the lowland) and Ferric and Plintic luvisols (northern of the Plateau department) (FAO, 2006) are dominant soils of the study area. Rainfall in those districts ranges between 900 and $1300 \mathrm{~mm}$ per year (Nouy, 1999), which provides good growth conditions of the oil palm trees, compared to other districts of Benin.

Soil sampling. Farmers' mature oil palm plantations (more than 6 years, Von Uexkull and Fairhurst, 1991) were used for the identification of nutrient deficiency symptoms manifestation (Kindohoundé et al., 2018). A binomial approximation formula of Dagnelie (1998) was used to define the size of the plantation, from which soil samples were collected.

Sampling was done in 214 farmers' mature oil palm plantations (with an average of 2.5 ha per farmer); 108 in the district of Ouémé and 106 in the district of Plateau. For each sampled site, the distribution of nutrient deficiency symptoms, and the history of land use and the soil nature were recorded across both diagonals, especially at the extremities of

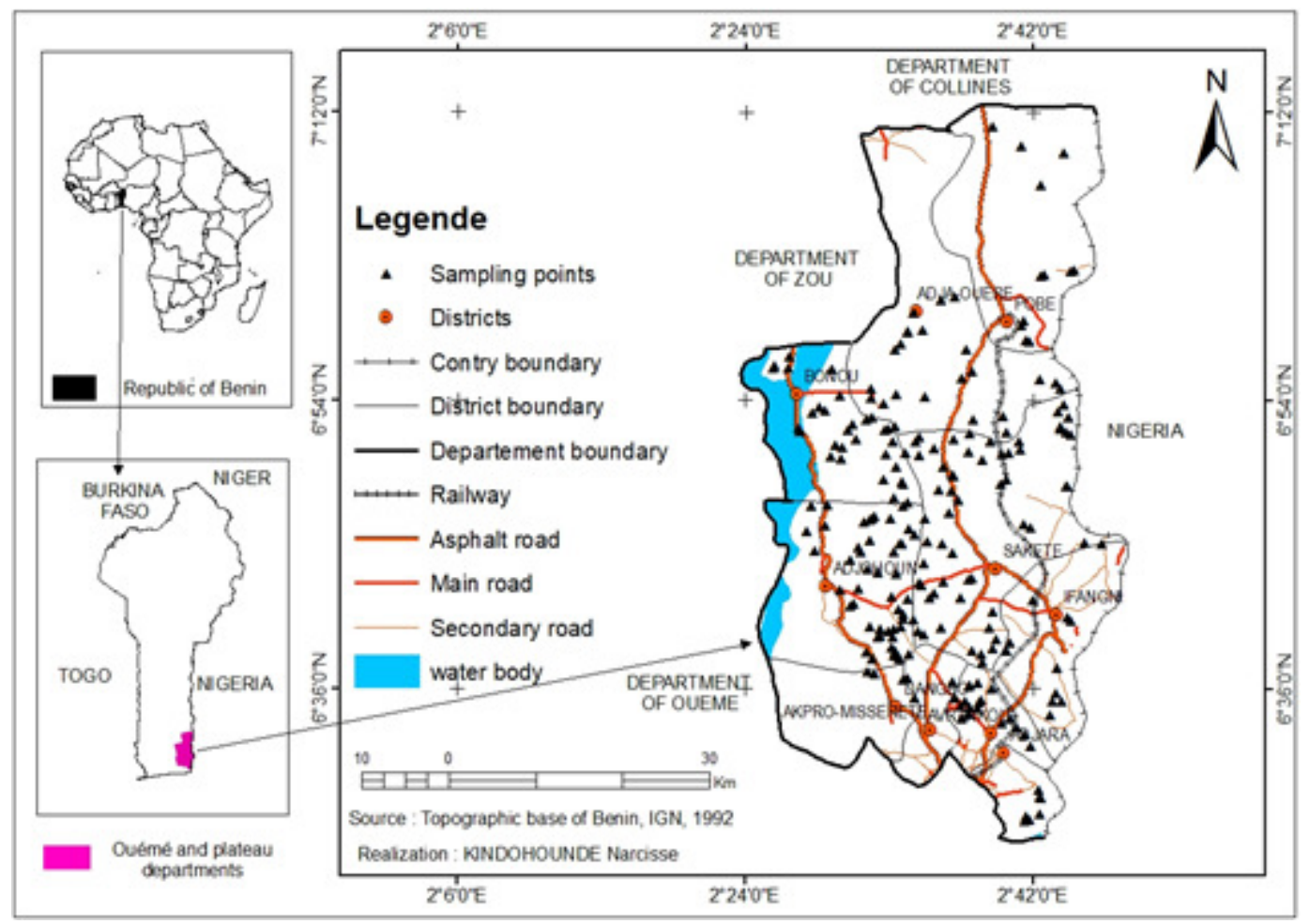

Figure 1. Study area and sampling points in oil palm plantations in Benin. 
diagonals and the centre of the field. But when land size was less than 1 ha, soil samples were only collected from both extremities and the centre of the field.

The oil palm trees were randomly selected before soil sampling. The procedure developed by Behera et al. $(2015,2016)$ was adopted and soil samples were collected under three oil palm trees (for plantation $<1$ ha) or five (for plantation $>1$ ha).

Composite soil samples were taken at 0 30 and 30-60 cm depth, around the oil palm trees, as the majority of oil palm's roots were concentrated at $0-60 \mathrm{~cm}$ depth. Due to fair soil homogeneity observed in the oil palm plantation, subsamples collected in each of area defined were mixed to constitute composite sample considering each soil depth and per oil palm plantation. Finally, 428 composite samples of approximately $500 \mathrm{~g}$ each were collected (214 composite samples for each depth), air dried and sieved at through $2 \mathrm{~mm}$, before sealing in polythene bags for analysis at laboratory. The latitude, longitude, and elevation at each sampling point were recorded using global positioning system (GPS).

Soil analysis. The samples were analysed for soil physical and chemical characteristics. Soil particle sizes were determined using Robinson pipette method, $\mathrm{pH}$ (water) was determined based on soil/water 1: $2.5 \mathrm{v} / \mathrm{v}$ ratio, using the potentiometric method (Jackson, 1973). Total $\mathrm{N}$ was determined using micro-Kjeldahl digestion in $\mathrm{H}_{2} \mathrm{SO}_{4}$ and Selenium, followed by distillation and titration. Exchangeable $\mathrm{Ca}^{2+}$ and $\mathrm{Mg}^{2+}$ were determined by atomic absorption spectrophotometry; and $\mathrm{K}^{+}$by flame photometry. Before the test, samples were extracted following standard procedures. Phosphorus was measured colorimetrically by ammonium molybdate with ascorbic acid at a wavelength of $660 \mathrm{~nm}$. The analyses were carried out at the Laboratory of Soil Science Water and Environment of the Benin National Agricultural Research Institute (INRAB).
Data analysis. The descriptive statistics (mean and standard deviation) were calculated for each soil property using XLSTAT software. In addition, a two-way analysis of variance was done for each nutrient, considering the soil depth and soil type. The means were compared using Student Newman Keuls test at $5 \%$ level. The critical nutrient concentration value in the soil for mature oil palm elaborated by Goh and Chew (1997) for nitrogen and phosphorus, Young and Brown (1962) (K and $\mathrm{Ca})$, Rossiter and van Wambeke (1993) (Mg) and Jacquemard (2011) (pH and CEC) was used to assess deficiency level (Table 1) in the oil palm plantation.

Geostatistical analysis. The spatial distribution of soil nutrient concentrations was established on a map to appreciate the correlation between them; and make relationships with oil palm tree's leaf symptoms. Variograms or semi-variograms (Christakos et al., 2002) were achieved to highlight the spatial correlation previously observed by kindohoundé et al. (2018). Different variogram model (exponential, spherical, Gaussian and Matern) were evaluated to determine the best fit for explaining the spatial structure of each variable. The models were compared and variograms constructed using autofit Variogram function of the package of automap (Hiemstra et al., 2008). From the best fitted model of variogram, nutrient concentrations in the oil palm plantations were predicted using ordinary kriging (Christakos et al., 2002; Kumar and Remadevi, 2006), following the auto Krige function of the automap package of $\mathrm{R}$ software version 3.5.3 ( $\mathrm{R}$ Core Team, 2019).

Mineral deficiency maps of each nutrient were developed using ArcGIS 10.4.1 software (Esri, Los Angeles, USA), based on the previous predictions homogeneous sites and classes of nutrient deficiency status.

The experimental semivariograms of soil properties were derived from Equation 1: 
Mapping of soil nutrient deficiency in oil palm plantations

$y(h)=\frac{1}{2 N(h)} \sum_{i=1}^{N(h)}[Z(X i+h)-Z(X i)]^{2}$

Equation 1

Where:

$\tilde{a}(h)$ is the experimental semivariogram, $h$ is the lag, $N(h)$ is number of sample value pairs separated by $h ; Z\left(X_{i}\right)$ and $Z\left(X_{i}+h\right)$ are sample values at two points at $X_{i}$ and $\left(X_{i}+h\right)$ locations, respectively.

The distance between the sample pairs is rarely equal to $h$ in irregular sampling, and $h$ is often represented by a distance interval. The semivariogram parameters like nugget/sill ratio and range, were obtained for soil properties. The nugget/sill ratio was used to classify the spatial dependency of the variables (Oliver and Webster, 2014). Ratios less than or equal to 0.25 , between 0.25 , and 0.75 , more than 0.75 were considered strongly, moderately and weakly spatially dependent, respectively (Cambardella et al. 1994).

\section{RESULTS}

Soil properties in oil palm plantations. Soil characteristics in the different oil palm plantations are presented in Table 2. It appears that the soils are mostly sandy loam texture, except vertisols. Soil $\mathrm{pH}$ were neutral to slightly acid. The highest $\mathrm{N}$ value was recorded in the Plintic and luvisol, and the lowest in the Hydromorphic soil. The highest concentration of available $\mathrm{P}$ was recorded in the Hydromorphic soil and the lowest in the Vertisols. As for the CEC, the highest value of was registered on the Plintic and luvisol; while the lowest was in the Hydromorphic soil. Exchangeable cations followed a similar trend.

Generally, total nitrogen values were under the threshold value of soil nitrogen, $0.8 \mathrm{~g} \mathrm{~kg}^{-1}$ (Table 1), and exchangeable potassium was also less than the threshold value of $0.20 \mathrm{cmol}$ $\mathrm{kg}^{-1}$ (Table 1). Consequently, nitrogen and potassium contents are deficient in most of 
TABLE 2. Means values of soil properties of soils under oil palm plantations in south Benin

\begin{tabular}{|c|c|c|c|c|c|c|c|c|c|}
\hline Type of soil & $\begin{array}{l}\text { Depth } \\
(\mathrm{cm})\end{array}$ & $\begin{array}{l}\text { Texture } \\
\text { classes }\end{array}$ & $\mathrm{pH}\left(\mathrm{H}_{2} \mathrm{O}\right)$ & 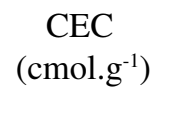 & $\begin{array}{l}\text { Total N } \\
\left(\mathrm{g} \cdot \mathrm{kg}^{-1}\right)\end{array}$ & $\begin{array}{r}\text { Available P } \\
\quad\left(\mathrm{mg} \mathrm{kg}^{-1}\right)\end{array}$ & $\begin{array}{c}\text { Exchangeable } \\
\mathrm{K}^{+} \\
\left(\mathrm{cmol} . \mathrm{kg}^{-1}\right)\end{array}$ & $\begin{array}{c}\text { Exchangeable } \\
\mathrm{Mg}^{2+} \\
\left(\mathrm{cmol} . \mathrm{kg}^{-1}\right)\end{array}$ & $\begin{array}{c}\text { Exchangeable } \\
\qquad \mathrm{Ca}^{2+} \\
\left(\mathrm{cmol}^{\mathrm{kg}} \mathrm{kg}^{-1}\right)\end{array}$ \\
\hline \multirow[t]{3}{*}{ Acrisol } & $0-30$ & Loamy sand & $5.82 \pm 0.04 \mathrm{a}$ & $5.54 \pm 0.23 \mathrm{ab}$ & $0.60 \pm 0.01 \mathrm{ab}$ & $29.99 \pm 4.35 \mathrm{a}$ & $0.17 \pm 0.01 \mathrm{a}$ & $0.92 \pm 0.06 \mathrm{a}$ & $2.15 \pm 0.13 a$ \\
\hline & $30-60$ & Loamy sand & $5.69 \pm 0.04 \mathrm{a}$ & $5.58 \pm 0.23 \mathrm{ab}$ & $0.51 \pm 0.01 \mathrm{ab}$ & $17.21 \pm 4.35 \mathrm{a}$ & $0.15 \pm 0.01 \mathrm{a}$ & $0.87 \pm 0.06 \mathrm{a}$ & $1.98 \pm 0.13 \mathrm{a}$ \\
\hline & Means & & $5.76 \pm 0.03 b$ & $5.56 \pm 0.17 \mathrm{a}$ & $0.55 \pm 0.01 \mathrm{~b}$ & $23.60 \pm 03.08 \mathrm{a}$ & $0.16 \pm 0.001 \mathrm{a}$ & $0.89 \pm 0.04 b$ & $2.07 \pm 0.09 \mathrm{ab}$ \\
\hline \multirow[t]{3}{*}{ Plintic and luvisol } & $0-30$ & Loamy sand & $5.47 \pm 0.15 \mathrm{a}$ & $7.19 \pm 0.96 \mathrm{ab}$ & $0.75 \pm 0.06 b$ & $17.41 \pm 17.84 \mathrm{a}$ & $0.20 \pm 0.03 a$ & $1.07 \pm 0.24 \mathrm{a}$ & $2.74 \pm 0.54 a$ \\
\hline & $30-60$ & Loamy sand & $5.43 \pm 0.15 \mathrm{a}$ & $8.12 \pm 0.96 b$ & $0.59 \pm 0.06 \mathrm{ab}$ & $11.07 \pm 17.84 \mathrm{a}$ & $0.17 \pm 0.03 a$ & $1.03 \pm 0.24 \mathrm{a}$ & $2.61 \pm 0.54 \mathrm{a}$ \\
\hline & Means & & $5.45 \pm 0.10 \mathrm{a}$ & $7.66 \pm 0.68 b$ & $0.67 \pm 0.04 b$ & $14.24 \pm 12.61 \mathrm{a}$ & $0.18 \pm 0.02 \mathrm{a}$ & $1.05 \pm 0.17 \mathrm{~b}$ & $2.67 \pm 0.38 b$ \\
\hline \multirow[t]{3}{*}{ Hydromorphic } & $0-30$ & Sand & $5.525 \pm 0.14 \mathrm{a}$ & $3.68 \pm 0.88 \mathrm{a}$ & $0.42 \pm 0.05 \mathrm{a}$ & $50.22 \pm 16.41 \mathrm{a}$ & $0.22 \pm 0.03 a$ & $0.49 \pm 0.22 \mathrm{a}$ & $1.32 \pm 0.50 \mathrm{a}$ \\
\hline & $30-60$ & Loamy sand & $5.41 \pm 0.14 \mathrm{a}$ & $5.05 \pm 0.88 \mathrm{ab}$ & $0.38 \pm 0.05 \mathrm{a}$ & $33.33 \pm 16.41 \mathrm{a}$ & $0.18 \pm 0.03 a$ & $0.47 \pm 0.22 \mathrm{a}$ & $1.19 \pm 0.50 \mathrm{a}$ \\
\hline & Means & & $5.47 \pm 0.09 \mathrm{a}$ & $4.37 \pm 0.63 \mathrm{a}$ & $0.40 \pm 0.04 \mathrm{a}$ & $41.78 \pm 11.60 \mathrm{a}$ & $0.20 \pm 0.02 \mathrm{a}$ & $0.48 \pm 0.16 \mathrm{a}$ & $1.26 \pm 0.35 \mathrm{a}$ \\
\hline \multirow[t]{3}{*}{ Vertisols } & $0-30$ & Clay & $5.73 \pm 0.22 \mathrm{a}$ & $6.26 \pm 1.43 \mathrm{ab}$ & $0.61 \pm 0.09 \mathrm{ab}$ & $8.63 \pm 26.46 \mathrm{a}$ & $0.13 \pm 0.05 \mathrm{a}$ & $0.84 \pm 0.36 \mathrm{a}$ & $2.44 \pm 0.80 \mathrm{a}$ \\
\hline & $30-60$ & Clay & $5.62 \pm 0.22 \mathrm{a}$ & $5.99 \pm 1.43 \mathrm{ab}$ & $0.47 \pm 0.09 \mathrm{ab}$ & $9.61 \pm 26.46 \mathrm{a}$ & $0.11 \pm 0.05 \mathrm{a}$ & $0.71 \pm 0.36 \mathrm{a}$ & $1.96 \pm 0.81 \mathrm{a}$ \\
\hline & Means & & $5.67 \pm 0.15 \mathrm{ab}$ & $6.14 \pm 1.01 \mathrm{ab}$ & $0.54 \pm 0.06 \mathrm{ab}$ & $9.12 \pm 18.71 \mathrm{a}$ & $0.12 \pm 0.03 \mathrm{a}$ & $0.78 \pm 0.25 \mathrm{ab}$ & $2.20 \pm 0.57 \mathrm{ab}$ \\
\hline
\end{tabular}

Means followed by the same alphabetic letters are not significantly different $(\mathrm{P}>0.05)$ according to the test of Student Newman Keuls 
the soil in the study area. Available phosphorus values were also below the threshold of 10 $25 \mathrm{mg} \mathrm{kg}^{-1}$ ) (Table 1) in the Acrisol, Plintic and Luvisols and in the Vertisols.

Overall, levels of exchangeable magnesium and calcium compared closely with the threshold values for all soil types. Magnesium presented moderate levels in the Hydromorphic soil type (Table 2 ).

Figure 2 presents the number of oil palm plantation showing nutrients deficiency by soil types. It is clear that most of the oil palm plantations showed nitrogen (100\%), potassium (88\%) and phosphorus (76\%) deficiency. Calcium and $\mathrm{Mg}^{2+}$ showed moderate deficiency in the oil palm fields.

Spatial distribution of nutrient deficiency status. The best fit model and semivariogram parameters obtained from the geostatistical analysis are presented in the Figure 3. The spatial dependency of soil nutrients varied from moderate to strong in the oil palm plantations by soil types. According to the spatial dependency ratio, it appears that total nitrogen (0\%), available phosphorus $(0.05 \%)$, exchangeable potassium ( $0 \%)$ and magnesium $(0 \%)$ had a strong (nugget/sill ratio $<25 \%)$ spatial dependency; whereas exchangeable calcium $(38 \%)$ showed moderate spatial dependency (nugget/sill ratio between 25 and $75 \%$ ).

Soil nutrient concentrations varied spatially in the oil palm plantations by soil types, between 1.12 and $16.13 \mathrm{Km}$. The lowest range of values was observed with total $\mathrm{N}(22.4$ $\mathrm{Km}$ ), exchangeable $\mathrm{K}^{+}, \mathrm{Mg}^{2+}$, and $\mathrm{Ca}^{2+}$ (1.12, $1.12 \mathrm{Km}$ and $26.88 \mathrm{Km}$ respectively); whereas the range value of available $\mathrm{P}(16.13 \mathrm{Km})$ was the largest.

Prediction of nutrient concentration in the oil palm plantation regarding the soil types, considering the best model of variogram is presented in Figure 4. The prediction shows variation of each soil nutrient concentration and light homogeneity zones in the oil palm plantations. Figure 5 presents soil nutrient deficiency maps obtained using the previous prediction of nutrients concentration by kriging interpolation, associated with the different classes of nutrients status. In general, the oil palm plantations' soils are deficient in nitrogen.

The soils of the oil palm plantations were deficient in exchangeable $\mathrm{K}^{+}$and available $\mathrm{P}$, except in the districts of Bonou, Adjohoun, Dangbo, Akpro-Missérété, Avrankou and Adjarra, Ifangni and Sakété where available $\mathrm{P}$ were at some optimum, moderate and high level. In these areas, small homogeny areas were classified as moderate, optimum and high phosphorus deficiency. The oil palm plantations of these areas presented optimum to high exchangeable $\mathrm{Mg}^{2+}$ and $\mathrm{Ca}^{2+}$ soil levels.

Soil nutrient deficiency maps of the oil palm plantation show two large areas presenting similar deficiency (Fig. 5). The first zone includes districts of Bonou, Adjohoun, Sakété, Adja-Ouèrè, and Pobè (soils are deficient in total nitrogen, available $\mathrm{P}$ and exchangeable $\mathrm{K}^{+}$); while the second zone includes Dangbo, Missérété, Ifangni, Avrankou, Adjarra present deficiency in total nitrogen, exchangeable $\mathrm{K}^{+}$ and available $\mathrm{P}$ (slightly deficient at some point).

In general, the kriging interpolation maps of the soils under oil palm plantation are almost deficient in total $\mathrm{N}$, available $\mathrm{P}$ and exchangeable $\mathrm{K}^{+}$(Fig. 5a, b and c).

\section{DISCUSSION}

Soil properties in oil palm plantations. Results of the present study showed that soils under oil palm plantation are threatened with nutrient depletion. Total nitrogen, exchangeable $\mathrm{K}^{+}$and available $\mathrm{P}$ are deficient in the different soil types under oil palm plantation in the study area. However, for exchangeable $\mathrm{Mg}^{2+}$, only the oil palm plantations on Vertisols did not show deficiency. The Acrisols did not present exchangeable $\mathrm{Ca}^{2+}$ deficiency. These results are partly consequent to inadequate fertiliser management in the farmers' fields, which does not guarantee sustainable oil palm productivity. Moreover, oil palm is a tree with high nutrient requirement and, therefore, nutrient supply must adequately compensate for potential 

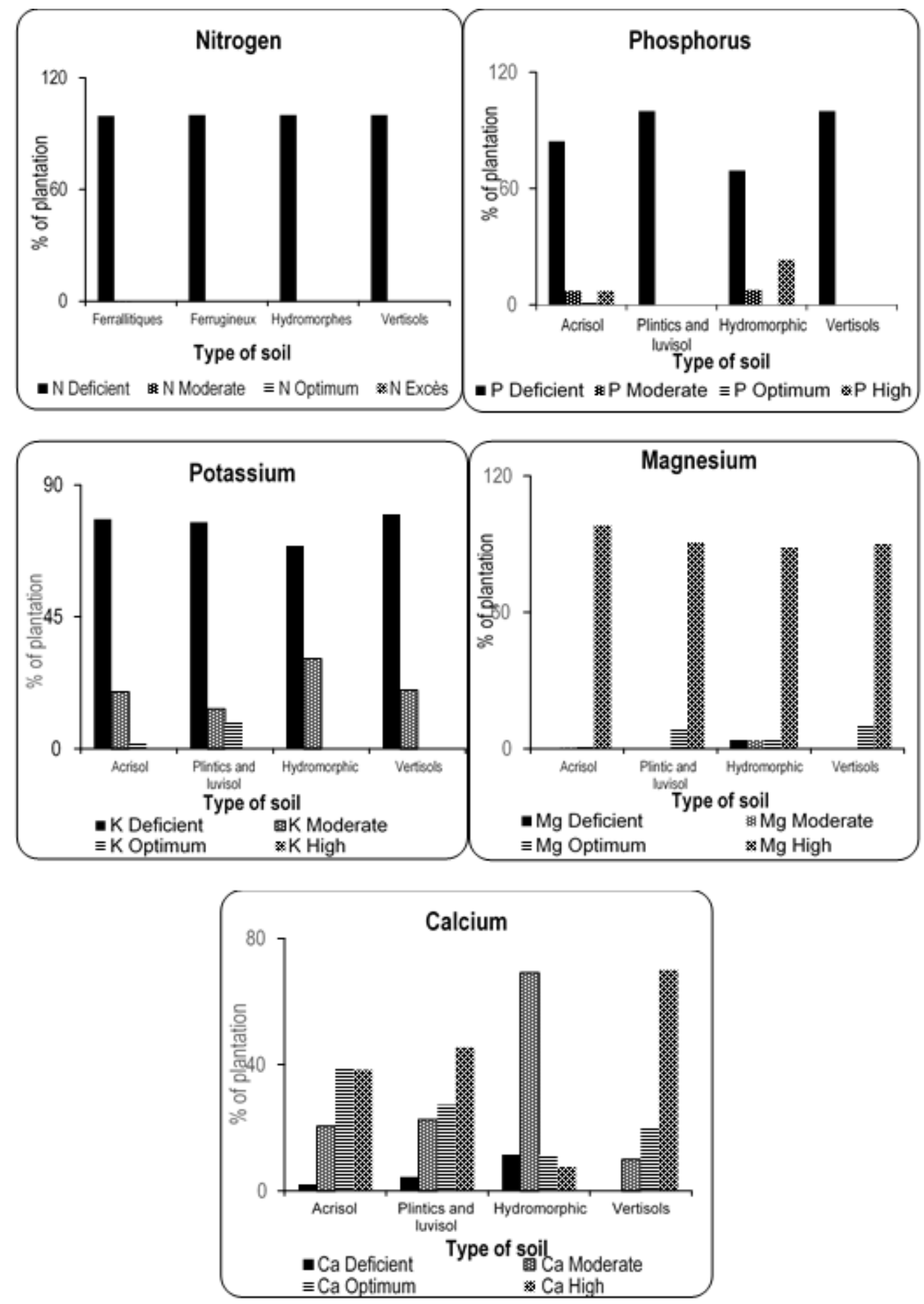

Figure 2. Nutrient sufficiency rating for different soil types under oil palm plantation at different soil depths in Benin. 
Mapping of soil nutrient deficiency in oil palm plantations
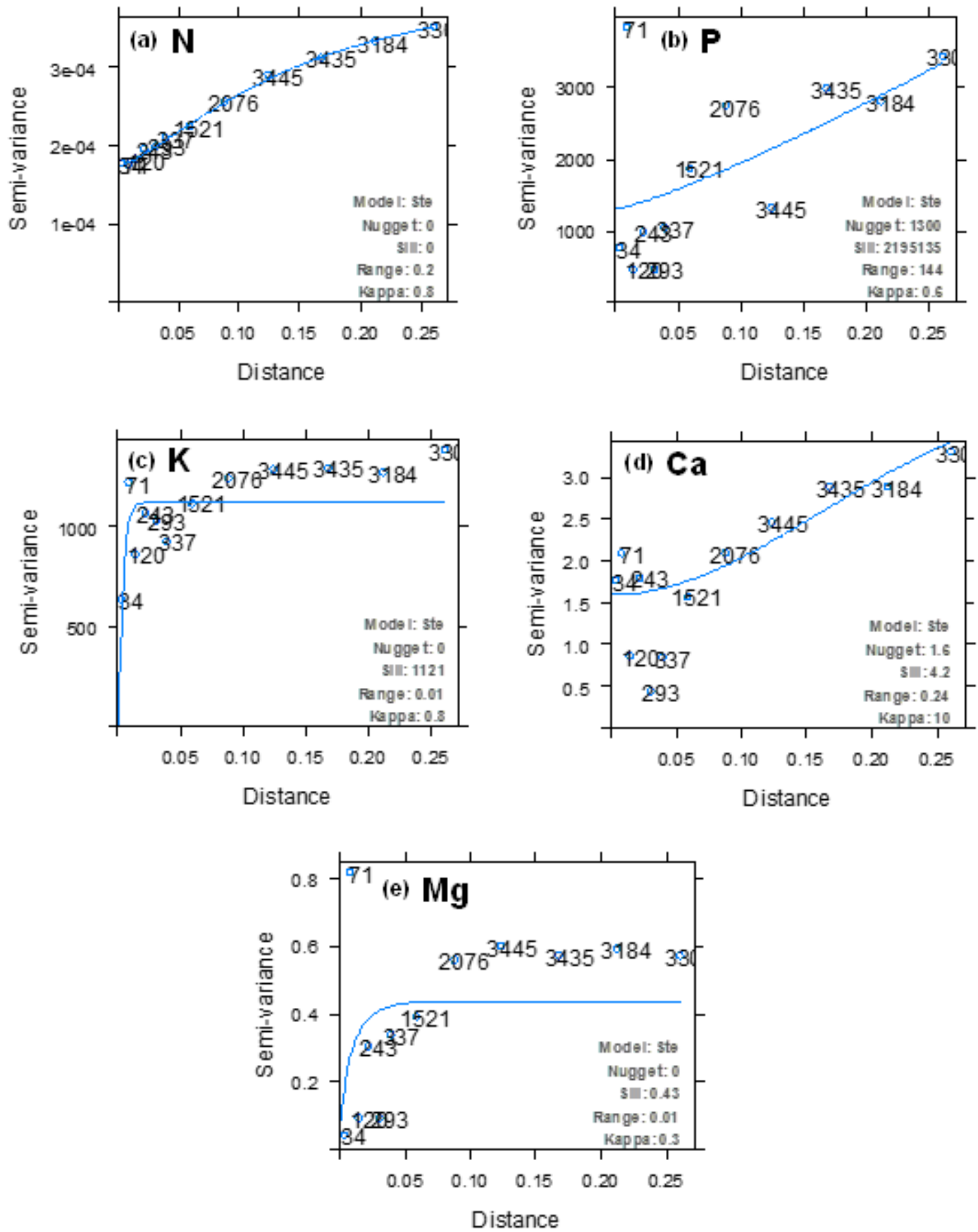

Distances are expressed in $\left(^{\circ}\right): 1$ degree $=112 \mathrm{Km}$

Figure 3. Variogram of soil nutrients in the study of area: nitrogen (a), phosphorus (b), potassium (c), calcium (d) and magnesium (e). 
150

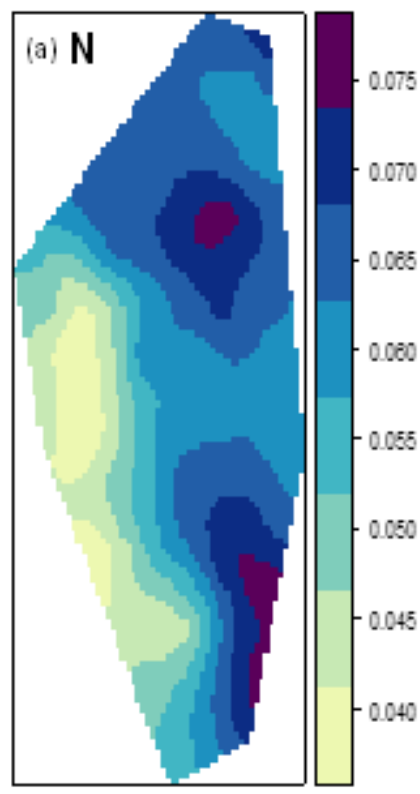

N.S. KINDOHOUNDÉ et al.

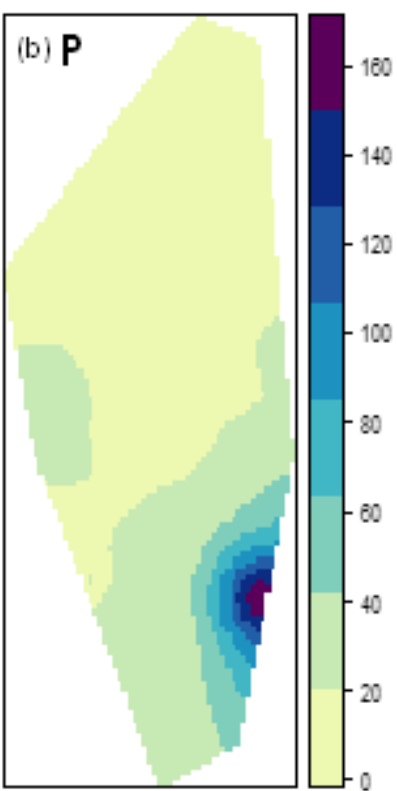

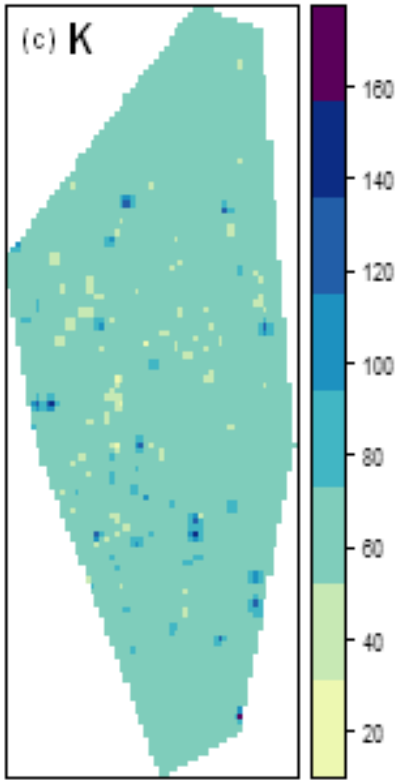

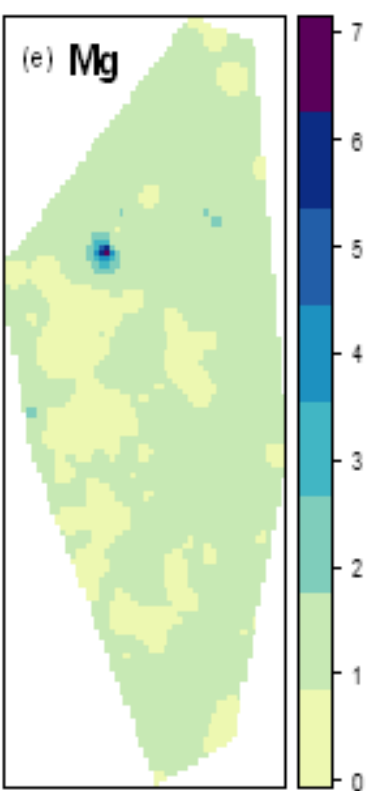

Figure 4. Assessment of nutrient concentrations in soil (depth of 0-30 cm) of oil palm plantations in southern Benin. Nitrogen (a), Phosphorus (b), Potassium (c), Calcium (d), and Magnesium (e). 
Mapping of soil nutrient deficiency in oil palm plantations

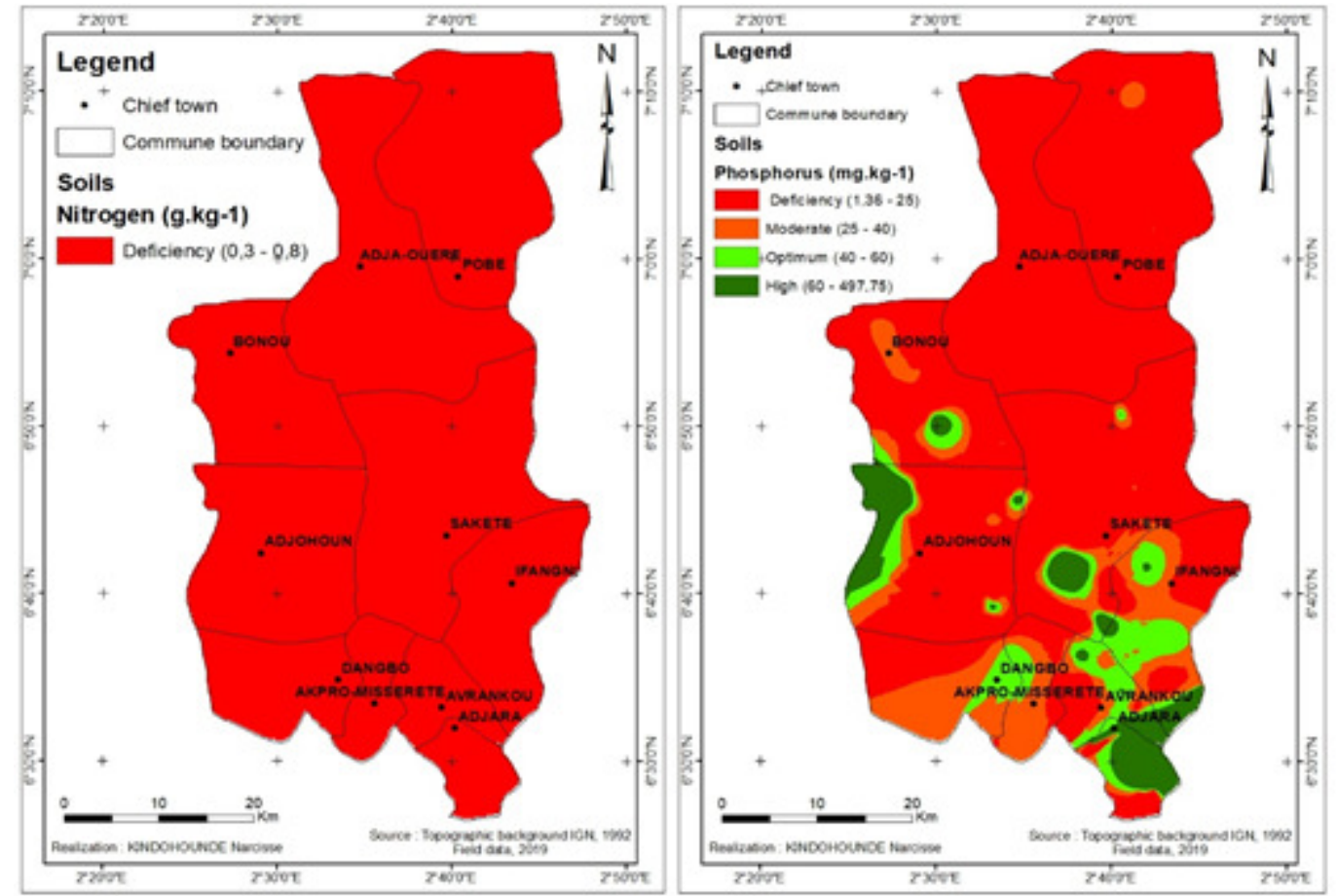

a
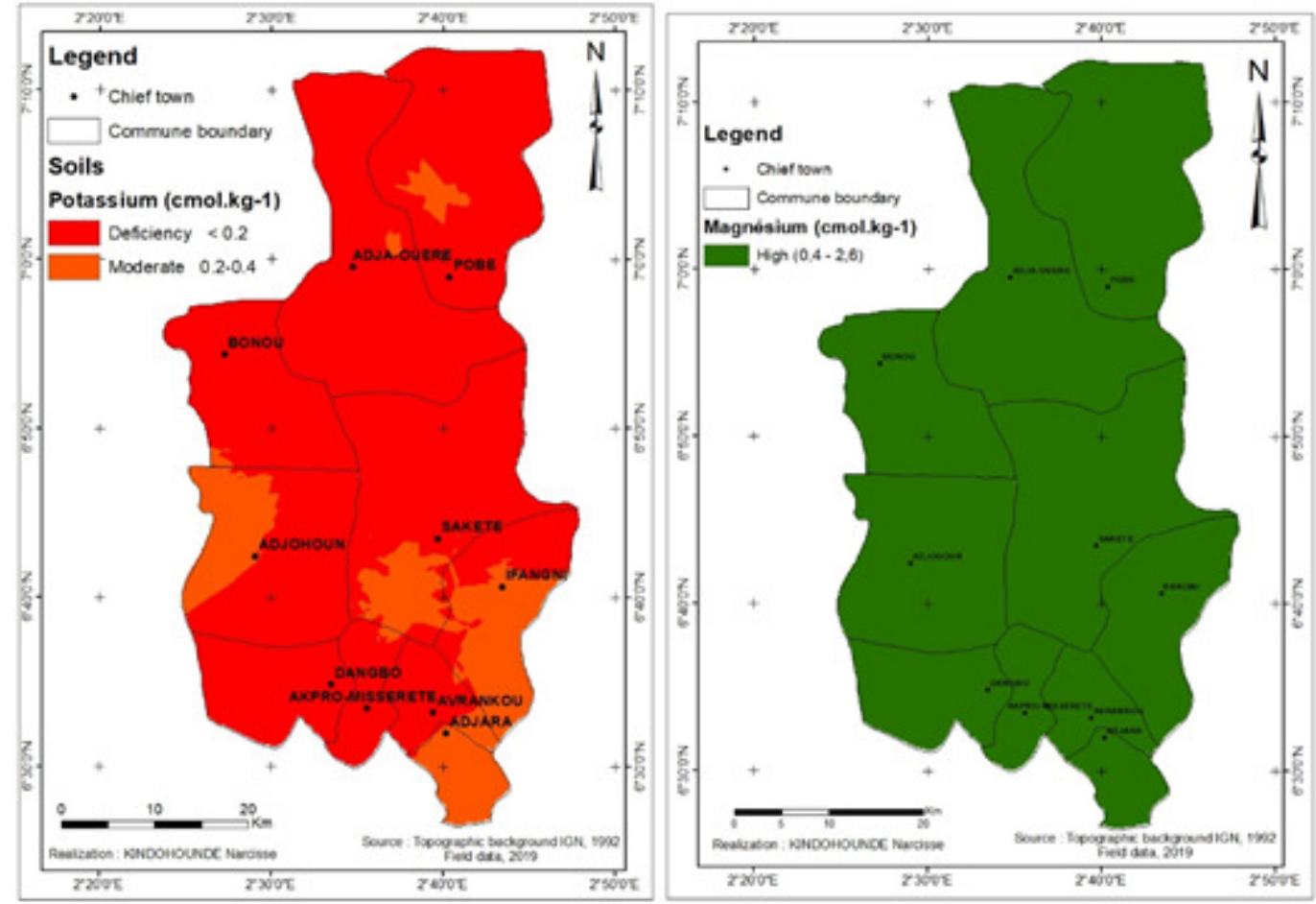

c 


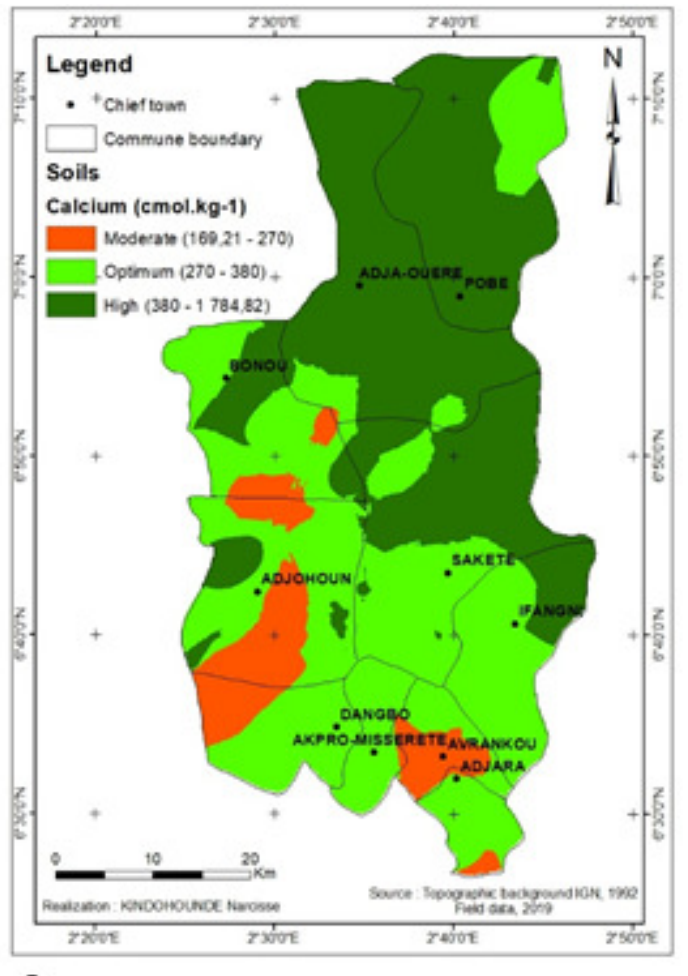

e

Figure 5. Soil nutrients (depth of 0-30 cm) status spatial mappings in oil palm plantations in southern Benin. (a) nitrogen, (b) phosphorus, (c) potassium, (d) magnesium, and (e) calcium.

nutrient depletion. In addition, our results showed that soil nutrient concentrations decrease from top layer to deep layer. These results might be due to the organic matter content derived from the decomposition of the biomass under the oil palm plantation. The fronds of the oil palm are always let by the farmers around the trees and are sometimes put in swath.

In general, total nitrogen in the oil palm plantation was classified as deficient (Table 2). Low nitrogen concentrations in the soil could be due to many factors, especially the nonapplication of fertilisers; nutrient leaching from the soil; and loss through runoff and erosion processes (Gasim et al., 2013; Mohidin et al., 2015). According to Aholoukpè et al. (2013) and Kindohoundé et al. (2018), oil palm plantation owners in the study area hardly used fertilisers regularly; such practice could cause soil nutrient mining, further causing nitrogen deficiency.

In the farmers' oil palm plantations, soil available $\mathrm{P}$ concentrations across soil types, were virtually deficient (Table 2). According to Rendana et al. (2016), low amounts of phosphorus is normally associated with high $\mathrm{Al}$ concentration in the soil, erosion and nonsufficient phosphate fertiliser application to the trees. In fact, the type of fertiliser applied (most growers apply urea $+\mathrm{KCl}$ ) by farmers did not contain sufficient $P$ nutrient to satisfy the oil palm tree demand. Phosphorus is an important nutrient for the plant growth and quality fruit production, yet it is on the verge of depletion even though Kindohoundé $e t$ al. (2018) hardly found leaves with P deficiency symptoms.

Soil exchangeable $\mathrm{K}^{+}$in the oil palm plantation for the different soil types was almost 
deficient, confirming the leaf discolouration observed by Kindohoundé et al. (2018). The exchangeable $\mathrm{K}^{+}$level in the soil is influenced by soil $\mathrm{pH}$ (Hargreaves et al., 2015), which at low level interferes with the adsorption of exchangeable $\mathrm{K}^{+}$. Besides, the presence of calcium and magnesium in the process of cation exchange, might also lead to low potassium concentrations in soil (Rendana et al., 2016).

As for exchangeable $\mathrm{Mg}^{2+}$ (at $0-30 \mathrm{~cm}$ depth), a high level was found in all the study area (Table 2). The calcium concentration in the soil was at optimum to high level in most of the oil palm plantation of the study area. This result is might be due to high CEC level in the soil, on one hand, and the $\mathrm{pH}$ values which could have induced low amount of soil calcium on the other hand. In addition, the strong bonding between $\mathrm{Ca}$ and clay (Plaster, 2009) in the soil protects the nutrient against leaching process. This could have increased $\mathrm{Ca}$ concentrations in the soil.

It was noticed from the present study that nutrient deficiency in the oil palm plantation varied according to the soil types. This corroborate Shukla et al. (2014), who mentioned also that cropping systems and anthropogenic activities could induce low $\mathrm{Ca}$ level in a field.

Soils under the oil palm plantation in the study area were deficient in total $\mathrm{N}$, available $\mathrm{P}$ and exchangeable $\mathrm{K}^{+}$. This could be due to the type of fertilisers (most growers apply urea $+\mathrm{KCl}$ ). Our results are in line with those of Rendana et al. (2016), who found N, P, K and $\mathrm{Mg}$ deficiencies in the oil palm plantation in India which could have been caused by factors including water erosion, $\mathrm{pH}$ and fertiliser application.

Spatial distribution of nutrient deficiency status. Our findings showed different nutrient distribution in the soil of the oil palm plantation of the study area. This can affect the oil palm yield at some point inside each plantation. However, traditional practices of fertilisation adopted by the oil palm growers, consisting of application of uniform nutrient doses regardless of soil micro variability, could be a constraint for oil palm yield improvement. In fact, fertiliser application in the oil palm plantation should be site specific, regarding soil heterogeneity.

Regular soil sampling should be done before fertiliser application to avoid over or under nutrient application. In the case of the present study, we can assert based on the work carried out by Kindohoundé et al. (2018) in the same oil palm plantation that nutrients were applied far below the required doses; as leaf discolourations were observed. Furthermore, according to Miransari and Mackenzie (2010), evaluation of spatial variability can be used for optimum fertiliser application recommendation as it suggests appropriate nutrients based on deficiency level in the soil. This can contribute suitably to enhanced tree crops' productivity.

Knowledge of spatial dependency and distribution of soil properties is crucial for natural resource evaluation and environmental management of un-surveyed locations (Behera et al., 2015). In contrast with our findings, Tesfahunegn et al. (2011) and Behera et al. (2015) reported best fit Gaussian model for total nitrogen and total phosphorus assessment, spherical for exchangeable $\mathrm{K}^{+}$, exponential for exchangeable $\mathrm{Ca}^{2+}$ and $\mathrm{Mg}^{2+}$ in Mai-Negus catchment (north Ethiopia) and southern plateau of India, respectively. This is probably due to the evolution of nutrient levels in the soil from one sampling point to another, in both study area. However, the best fitted model is the one which better estimates the variables with a positive variance. The criteria used to classify the spatial dependence variables were the percentage of nugget/sill ratio. With respect to these criteria, our findings showed strong and moderate spatial dependence for N, P, K, $\mathrm{Mg}$ and $\mathrm{Ca}$ (Fig. 3). Strong spatial dependence of soil properties observed in our study could be due to intrinsic factors, such as soil mineralogy, whereas, the moderate spatial dependence is the consequence of both 
intrinsic and extrinsic factors such as anthropogenic activities as mentioned by Behera et al. (2015).

The ranges estimated for (Fig. 3) are likely to be landscape dependent and could be explained by the distance through distinct soil types. Thus, soil samples separated by distances closer than the range are spatially related; whereas those separated by greater distances than the range are not spatially related. Our findings showed higher range values for $\mathrm{P}$, with great differences between ranges of soil properties in the study area. Behera et al. (2015) stated that large range values of a soil property indicate that soil properties measured were influenced by natural and anthropogenic factors, over greater distances. Several authors reported similar large differences between range values of soil characteristic when attempting to map variations (Tesfahunegn et al. 2011; Foroughifar et al. 2013).

Reliability of the nutrient maps for decision making. The mapping of soil nutrients in the farmers' oil palm plantations is a key method of assessing soil micro variability, to address a suitable site-specific fertiliser recommendation. The heterogeneity observed in the soil nutrient contents in the farmers' oil palm plantation, was used to design mineral deficiency map (Fig. 5), which indicated soil homogeneity inside a zone. This is crucial for planning appropriate soil fertility management strategies in the oil palm plantations, to achieve optimal yields. In fact, the zones showing low nutrient availability will require some heavier nutrient doses, compared to zones presenting high nutrient contents. The final remark is that one should consider soil heterogeneity in the oil palm plantation when applying fertilisers. This requires site specific nutrient application according to soil characteristic.

To make the nutrient mapping effective in decision making in order to improve oil palm production, we suggest a similar study on oil palm leaves; nutrient deficiency might occur in leaves as consequence of nutrient unbalance, which will limit the effect of oil palm fertiliser management based only on soil nutrient deficiency map. In fact, nutrient deficiency maps have been developed in Indonesia and were very useful in the sitspecific fertiliser development for oil palm production improvement. Because of limited budget, this study did not take into account all regions of oil palm production in Benin and, therefore, we suggest extending this study to other regions in order to have a global overview on soil nutrients distribution in oil palm production. We strongly believe that this study is a starting point for the improvement of the fertiliser generally recommended to farmer's oil palm.

\section{CONCLUSION}

This study has shown N, P and $\mathrm{K}$ deficiency in the farmer's oil palm plantation in most of the soils. Strong to moderate spatial dependency were observed for $\mathrm{N}, \mathrm{P}, \mathrm{K}, \mathrm{Mg}$ and $\mathrm{Ca}$. Soil of the oil palm plantations are heterogeneous, and present micro variability, which should be taking into account for fertiliser application. It is also suggested that fertiliser application in the oil palm plantation should be site specific, considering soil analysis results.

\section{REFERENCES}

Adhikari, P., Shukla, M.K. and Mexal, J.G. 2012. Spatial variability of soil properties in an arid ecosystem irrigated with treated municipal and industrial waste water. Soil Science 177(7):458-469. doi:10.1097/SS.0b013e318257c331.

Adjadi, E. 2012. Le développement du palmier à huile sélectionné au Bénin. Rapport d'étude. Actualisation des superficies plantées. CRAPP/Pobè. 9p.

Aholoukpè, H. 2013. Matière organique du sol et développement du palmier à huile sous 
différents modes de gestion des feuilles d'élagage. Cas des palmeraies villageoises du département du Plateau au Bénin. Thèse de doctorat. 294pp.

Behera, S.K. and Shukla, A.K. 2015. Spatial distribution of surface soil acidity, electrical conductivity, soil organic carbon content and exchangeable potassium, calcium and magnesium in some cropped acid soils of India. Land Degradation \& Development 26: 71-79. doi:10.1002/ldr.2306

Behera, S. K., Suresh, K., Narsimha Rao, B., Manoja, K. and Manorama, K. 2016. Soil nutrient status and leaf nutrient norms in oil palm (Elaeis guineensis Jacq.) plantations grown in the west coastal area of India. Communications in Soil Science and Plant Analysis 47:255-262.

Christakos, G., Bogaert, P. and Serre, M. 2002. Temporal GIS, with CD-ROM. Springer, New York. pp. 53-82

Dewi, W.S. 2007. The impact of forest use change to agriculture. PhD Thesis. Graduate Program, Faculty of Agriculture, University of Brawijaya, Malang, Indonesia. $254 \mathrm{pp}$.

FAO. 2006. World reference base for soil resources, 2nd edn. World Soil Ressources Reports $\mathrm{N}^{\circ} 103$. Food and Agriculture Organization of the United Nations, Rome, Italy, 145pp.

Fageria, N.K., Baligar, V.C. and Clark, R.B. 2002. Micronutrients in crop production. Advances in Agronomy 77:185-250. doi:10.1016/S00652113(02)77015-6.

Foroughifar, H., Pakpour, A., Jafarzadeh, A.A., Miransari, M. and Torabi, H. 2013. Using geostatistics and geographic information system techniques to characterise spatial variability of soil properties, including micronutrients. Communications in Soil Science and Plant Analysis 44(12):73-81.

Gasim, M.B., Rahim, S.A., Toriman, M.E., Idris, W.M.R. and Lihan, T. 2013. Flux of nutrients and heavy metals from the Melai River sub-catchment into Lake Chini, Pekan, Pahang, Malaysia. Environmental Earth Sciences 68:889-897.
Goh, K.J. and Chew, P.S. 1997. Interpretations of analytical data from survey reports for manuring recommendations: Some pointers. Annual journal/Report, Royal Johore Planters' Association, 25-30.

Goovaerts, P. 1998. Geostatistical tools for characterizing the spatial variability of microbiological and physico-chemical soil parameters. Biology and Fertilityof Soils 27:315-334. doi:10.1007/s003740050439

Hiemstra, P.H., Pebesma, E.J., Twenhofel, C.J.W. and Heuvelink, G.B.M. 2009. Realtime automatic interpolation of ambient gamma dose rates from the Dutch Radioactivity Monitoring Network. Preprint submitted to Computers \& Geosciences, http:/www.opengeospatial. org/standards/wms.

Ilori, E.G., Okonjo, P.N., Ojeh, E., Isiekwe, M.U. and Aondona, O. 2014. Assessment of soil nutrient status of an oil palm plantation. Agricultural Journal 9:127-131.

Jackson, M.L. 1973. Soil Chemical Analysis. (Prentice Hall of India: New Delhi). 498pp.

Kindohoundé, S.N., Nodichao, L, Aholoukpè, N.S.H. and Saïdou, A. 2018. Symptômes de déficience minérale chez le palmier à huile (Elaeis guineensis jacq.) au niveau des sols du sud Bénin. Revue de Géographie du Bénin Université d'Abomey-Calavi (Bénin) Volume thématique. pp. 43-68.

Kumar, V. and Remadevi, 2006. Kriging of groundwater levels - A case study. Journal of Spatial Hydrology 6:81-94.

Miransari, M. and Mackenzie, A.F. 2010. Wheat (Triticum aestivum L.) grain $\mathrm{N}$ uptake as affected by soil total and mineral $\mathrm{N}$, for the determination of optimum $\mathrm{N}$ fertiliser rates for wheat production. Communications in Soil Science and Plant Analysis 41(6):44-53.

Mohidin, H., Hanafi, M.M., Rafii, Y.M., Abdullah, S.N.A. and Idris, A.S. 2015. Determination of optimum levels of nitrogen, phosphorus and potassium of oil palm seedlings in solution culture. Bragantia 74:247-254. 
Oliver, M. A. and Webster, R. 2014. A tutorial guide to geostatistics: Computing and modelling variograms and kriging. Catena 113:56-79.

R Core Team. 2019. R: A language and environment for statistical computing. $\mathrm{R}$ Foundation for Statistical Computing, Vienna, Austria. URL https://www.Rproject.org/.

Rendana, M., Rahim, S. A., Idris, W.M.R., Lihan, T. and Rahman, Z. A. 2016. Mapping nutrient status in oil palm plantation using geographic information system. Asian Journal of Agricultural Research 10: 144-153. ISSN 1819-1894, doi: 10.3923/ ajar.2016.144.153.

Rossiter, D.G. and van Wambeke, A.R. 1993. Automated Land Evaluation Systme. ALES Version 4 User's Manual. Department of soil, Crop and Atmospheric Sciences, Cornell University, New York, Ithaca.

Seutloali, K.E. and Beckedahl, H.R. 2015. Understanding the factors inûuencing rill erosion on roadcuts in the south eastern region of South Africa. Solid Earth 6: 633641. doi:10.5194/se-6-633-2015.

Shukla, A.K., Tiwari, P.K. and Prakash, C. 2014. Micronutrients deûciencies vis-a-vis food and nutritional security of India. Indian Journal of Fertilisers 10:94-112.

Tesfahunegn, G.B., Tamene, L. and Vlek, L.P.G. 2011. Catchment-scale spatial variability of soil properties and implications on site-speciûc soil management in northern Ethiopia. Soil \& Tillage Research 117:124-139. doi: 10.1016/j.still.2011.09. 005

Plaster, E.J. 2009. Soil Science and Management. 5th Edn., Delmar Cengage Learning, Australia. 448pp.

Von Uexkull, H.R. and Fairhurst, T.H. 1991. Fertilizing for high yield and quality: The oil palm. International Potash Institute, Bern, Switzerland. 79pp.

Young, A. and Brown, P.E. 1962. The physical environment of northen Nyasaland with special reference to soil and agriculture. Government Printer, Malawi. 107pp. 